\title{
Internal insulation applied in heritage multi-storey buildings with wooden beams embedded in solid masonry brick facades
}

\author{
Harrestrup, Maria; Svendsen, Svend
}

Published in:

Building and Environment

Link to article, DOI:

10.1016/j.buildenv.2016.01.019

Publication date:

2016

Document Version

Peer reviewed version

Link back to DTU Orbit

Citation (APA):

Harrestrup, M., \& Svendsen, S. (2016). Internal insulation applied in heritage multi-storey buildings with wooden beams embedded in solid masonry brick facades. Building and Environment, 99, 59-72.

https://doi.org/10.1016/j.buildenv.2016.01.019

\section{General rights}

Copyright and moral rights for the publications made accessible in the public portal are retained by the authors and/or other copyright owners and it is a condition of accessing publications that users recognise and abide by the legal requirements associated with these rights.

- Users may download and print one copy of any publication from the public portal for the purpose of private study or research.

- You may not further distribute the material or use it for any profit-making activity or commercial gain

- You may freely distribute the URL identifying the publication in the public portal

If you believe that this document breaches copyright please contact us providing details, and we will remove access to the work immediately and investigate your claim. 


\title{
Internal insulation applied in heritage multi-storey buildings with wooden beams embedded in solid masonry brick façades
}

\author{
M. Harrestrup ${ }^{* a}$, S. Svendsen ${ }^{\mathrm{b}}$
}

Section of Building Energy, Department of Civil Engineering, Technical University of Denmark (DTU), Building 118, Brovej, 2800 Kgs. Lyngby, Denmark

a: marih@byg.dtu.dk, Phone: (+45) 45255034

b: ss@byg.dtu.dk, Phone: (+45) 45251854

\begin{abstract}
Internal insulation is investigated in a building with a wooden beam construction and masonry brick walls. Measurements were carried out and used to validate a hygrothermal simulation. The risk of mould growth in the wooden beams and in the interface between the insulation and the brick wall was evaluated. A solution with a $200 \mathrm{~mm}$ area without insulation above and below the floor/ceiling was investigated. At low rain exposure coefficients (Catch Ratio, $\mathrm{CR} \leq 0.1$ ) and with a wall orientation towards the west, this solution can be moisture-safe. However, it not recommended to apply internal insulation on a northorientated wall, and caution should be exercised also with a west-orientated wall.
\end{abstract}

Keywords: Internal insulation, mould growth, hygrothermal simulations, moisture safety, wooden beamends 


\section{Introduction}

Energy-retrofitting of existing buildings is vital to achieve energy reductions. Most old multi-storey buildings with solid brick walls and a wooden beam construction were built in the period between 1850 and 1920 (Engelmark, 1983)[1]. Approximately 20\% of all homes in Denmark today were built in that period and they represent a significant energy-saving potential (Rasmussen, 2011) [2], but challenges arise when it comes to retrofitting heritage buildings where the façade cannot be modified due to the architectural value of the building. Insulating the façade from the inside will result in colder façades and the drying potential of the wall will be reduced and increased freeze-thaw damage probability. Capillary flows in the bricks, however, is unaffected by insulation and is a powerful moisture redistribution mechanism (Straube and Schumacher, 2007) [3]. Condensation, which can lead to mould growth, can occur in the interface between the interior insulation and the brick wall (Christensen and Bunch-Nielsen, 2009[4]; Munch-Andersen, 2008[5]; Kolaitis et al., 2013[6]; Abuku et al., 2009[7]). Attention also needs to be given to the risk of mould growth and wood decay in the wooden beam construction. Krebs and Collet (1981) [8] studied temperature and moisture content measurements in 30 wooden beam ends for Danish climate conditions. They concluded that wind-driven rain did not have a significant influence and that there was only a very limited risk of moisture problems in the beam ends. However, Kehl et al.

(2013) [9] provide a literature review that concluded that wind-driven rain has an important influence on the behaviour of moisture content and the risk of beam end decay in the German climate conditions.

Ruisinger (2013) [10] compared five different internal insulation systems in the German climate in order to investigate the risk of damage to wooden beams, and found no hazard.

Morelli and Svendsen (2012) [11] carried out a theoretical investigation on various intensities of winddriven rain on façades using numerical simulation with climate data from north of Germany. They 
concluded that wind-driven rain has a great impact on the performance and durability of the wooden beam ends. They also concluded that if the internal insulation stops on the wall $200 \mathrm{~mm}$ above the floor, the risk of wood decay is minimised and heat losses can still be halved compared to a façade without insulation. However, it is important not only to look at the wood decay but also at the risk of mould growth. Several studies have tried to predict when there is a risk of mould growth on the wooden construction and in the interface between the insulation and the wall. According to Viitanen (1997) [12], there is a risk of mould growth on pine and sapwood if the relative humidity is above $80 \%$ for several weeks $/$ months and the temperature is between $5-50^{\circ} \mathrm{C}$. At temperatures between $0-5^{\circ} \mathrm{C}$, the mould growth is slow and only expected when the relative humidity is above $90 \%$. Viitanen et al. (2008) [13] state that there is no risk of mould growth that can create smell and health problems on a wooden surface when the relative humidity is less than $75 \%$. Sedlbauer (2001) [14] states that if the temperature is $30^{\circ} \mathrm{C}$, mould growth can occur at a relative humidity of $70 \%$. However, this is not so relevant since the critical places in the construction will have temperatures around $20^{\circ} \mathrm{C}$ and below, which require a relative humidity of more than 75-80\% to initiate any risks (Johansson et al, 2012[15]; Nielsen et al., 2004[16]; Grant et al., 1989 [17]; Johansson et al., 2013[18]). According to Sedlbauer (2002) [19], the critical limit for mould growth on the façade is at a relative humidity higher than $80-90 \%$, depending on the duration and temperature. Morelli (2014) [20] found that to avoid mould growth in the interface it is very important to clean the wall of any organic materials.

Johansson et al. (2014) [21] applied vacuum-insulating panels on the inside of a brick wall constructed with wooden beam ends and carried out laboratory tests and numerical simulations with various winddriven rain exposures and temperatures for Swedish climate conditions. They found that vacuum insulation showed considerable potential for reducing energy use, but also that the temperatures in the wall decreased significantly, which can lead to the risk of condensation in the interface between wall and insulation as well as higher moisture content in the wooden beam ends. According to Scheffler and 
Grunewald (2003) [22], capillary-active insulation materials can absorb the condensation and transfer it to the inside where it can dry out, and condensation in the interface can be avoided. However, Vereecken and Roels (2014) [23] compared different insulation systems in a laboratory and found that capillaryactive insulation materials accumulated more moisture in the interface between the insulation and brick wall than the traditional system using vapour-tight barriers.

Warren et al. (2003) [24] installed a heating pipe just above the floor construction and below the interior insulation to provide increased temperature to heat up the wooden beam construction and consequently decrease the moisture content. They concluded that this reduced the relative humidity by $10-14 \%$.

The research presented in this paper was aimed at investigating in more detail how the brick wall and wooden beam construction embedded in the brick wall is affected when internal insulation is applied. The hypothesis tested was: It is possible to apply internal insulation on the solid masonry brick wall in old heritage multi-storey buildings, without creating a risk of mould growth on the masonry wall and in the wooden beam construction. Various insulation solutions were investigated, each of which aimed at eliminating the risk of mould growth in a) the wooden beam construction and b) the interface between the insulation and brick wall. The solution suggested in Morelli and Svendsen (2012) [11] where the insulation stops $200 \mathrm{~mm}$ above the floor and below the ceiling was investigated in more detail, together with a solution where the insulation stops only above the floor, for various wall orientations and rain exposures. The research presented in this article gained new knowledge on the use of internal insulation in brick buildings with wooden beam constructions. Hygrothermal simulations and measurements carried out in a renovated building in Copenhagen were used to evaluate the effect on the wooden beam construction. The risk of mould growth was evaluated with a mathematical mould growth model. 


\section{Methods}

The method applied for this investigation was to carry out measurements in a test building to validate a hygrothermal simulation model created with Delphin Software 5.8. Since the measurements were only carried out in the wooden floor beams embedded in the masonry wall, only that part of the simulation could be validated. Another model for simulating the wall construction was created as a 1D-model to evaluate the risk of mould growth behind the insulation.

\subsection{Measurements in the wooden beam ends}

An old heritage multi-storey building from the beginning of the $20^{\text {th }}$ century in Copenhagen was renovated and internal insulation was applied shown in Figure 1(c). Morelli and Svendsen (2012) [11] and Harrestrup and Svendsen (2014) [25] suggest leaving a gap in the insulation $200 \mathrm{~mm}$ above the floor and below the ceiling to minimize moisture problems in the beam construction. For practical reasons, however, a gap in the insulation of 200 mm was only applied above the floor construction and not below the ceiling as shown in Figure 1(a). 40mm of insulation with a thermal conductivity of $0.019 \mathrm{~W} / \mathrm{mK}$ and a $10 \mathrm{~mm}$ gypsum board was applied to the façade. The insulation consists of a mixture of aerogel and mineral wool and was applied with an integrated vapour barrier; see the red line in Figure 1(a). The building is constructed with solid masonry bricks and wooden beams as the load-bearing construction. Temperature and relative humidity sensors were installed in the wooden beam ends and used to validate a simulation model (Figure $1(\mathrm{~b})$ ). The sensors were installed in two apartments on the $4^{\text {th }}$ and $5^{\text {th }}$ floor with the façade facing south-west. There are no obstacles close to the façade and the wall is therefore highly exposed to the weather, such as wind-driven rain. The measuring points can be seen in Figure 1(a). The indoor temperature and relative humidity were measured in the two apartments to evaluate the indoor climate and to use the data as input to the simulation model. 
a)

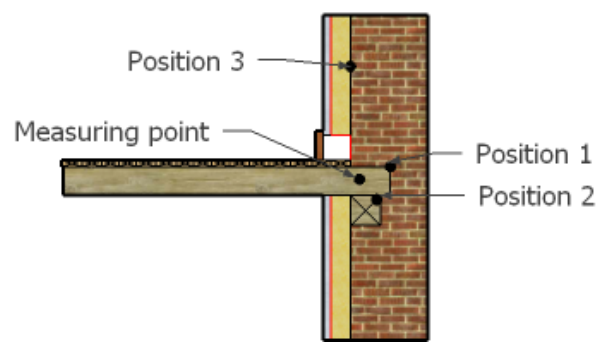

b)

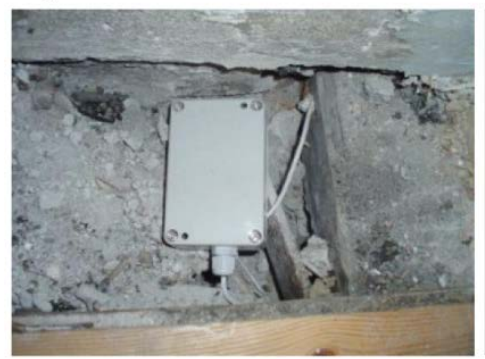

c)

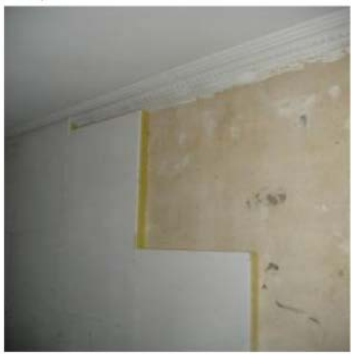

Figure 1: a): Internal insulation applied on the brick wall with an indication of measuring points and investigated areas in the construction, b) Temperature and RH sensors installed in the wooden floor beam ends, c) Internal insulation applied.

\subsection{Simulation model in Delphin Software}

The simulation models were created in Delphin software version 5.8, which is a hygrothermal twodimensional program. Using a two-dimensional program to analyse a three-dimensional problem implies great uncertainties with regard to the simulated results. In an attempt to reflect the three-dimensional problem, two sets of simulations were carried out to simulate worst-case scenarios. The assembly of the floor/exterior wall construction is shown in Figure 2(a). The wooden floor beams perpendicular to the exterior wall are spaced approximately 1 metre apart and supported by the load-bearing beam embedded in the exterior brick wall parallel to the exterior façade. One set of models were created with the wooden floor beam perpendicular to the exterior wall (Figure 2(b)), and the other set of models were created without the floor beam (Figure 2(c)). 

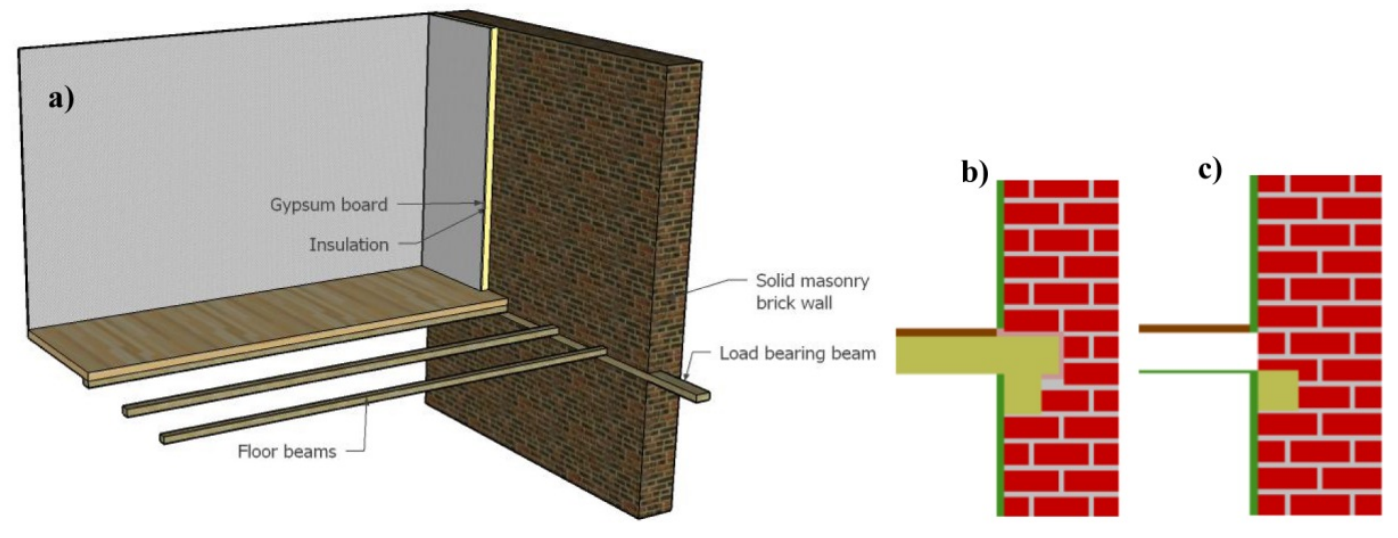

Figure 2: a) Assembly between the exterior wall and the floor construction. Wooden floor beams perpendicular to the façade are spaced approximately 1 metre apart on top of a load-bearing continuous wooden beam in the brick wall. Two sets of models were created in Delphin: $b$ ) with the floor beam and c) without the floor beam.

The exterior wall was constructed with bricks separated by lime mortar. The cross section area of the supporting beam is $150 \mathrm{~mm} \times 150 \mathrm{~mm}$ and the height of the wooden beam in the floor construction is 140 $\mathrm{mm}$. The floor was constructed as $30 \mathrm{~mm}$ wooden floor boards, and around the beam there is an air gap of $20 \mathrm{~mm}$. $30 \mathrm{~mm}$ of lime plaster was applied to the façade on the inside. The material properties are shown in Table 1. The liquid transfer resistance was modelled as a contact resistance at the interface between the bricks and the lime-cement mortar with a value of $5 \cdot 10^{10}\left(\mathrm{~m}^{2} \cdot \mathrm{s} \cdot \mathrm{Pa}\right) / \mathrm{kg}$. The vapour barrier was modelled as a contact resistance with a vapour diffusion resistance of $10.2 \cdot 10^{9}\left(\mathrm{~Pa} \cdot \mathrm{s} \cdot \mathrm{m}^{2}\right) / \mathrm{kg}$. 
Table 1: Material properties for simulations in Delphin 5.8

\begin{tabular}{|c|c|c|c|c|c|c|c|c|}
\hline Material properties & : & 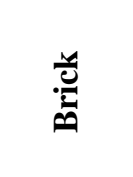 & 关营 & 甾茍 & 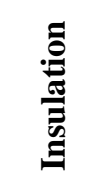 & 志 & 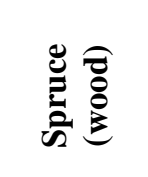 & $\begin{array}{l}\text { 今్ } \\
\text { : }\end{array}$ \\
\hline Density & $\mathrm{kg} / \mathrm{m}^{3}$ & 1788 & 1568 & 1800 & 30 & 850 & 528 & 1.3 \\
\hline Specific heat capacity & $\mathrm{J} /(\mathrm{kg} \cdot \mathrm{K})$ & 868 & 1000 & 850 & 840 & 850 & 2000 & 1000 \\
\hline Thermal conductivity & $\mathrm{W} /(\mathrm{m} \cdot \mathrm{K})$ & 0.91 & 0.70 & 0.82 & 0.019 & 0.20 & 0.13 & 0.27 \\
\hline Open porosity & $\mathrm{m}^{3} / \mathrm{m}^{3}$ & 0.35 & 0.41 & 0.30 & 0.92 & 0.65 & 0.70 & - \\
\hline Saturation moisture content & $\mathrm{m}^{3} / \mathrm{m}^{3}$ & 0.35 & 0.25 & 0.29 & 0.9 & 0.55 & 0.70 & - \\
\hline Capillary moisture content & $\mathrm{m}^{3} / \mathrm{m}^{3}$ & 0.26 & 0.25 & 0.25 & 0.9 & 0.40 & 0.55 & - \\
\hline Water absorption coefficient & $\mathrm{kg} /\left(\mathrm{m}^{2} \mathrm{~s}^{0.5}\right)$ & 0.227 & 0.300 & 0.127 & - & 0.277 & 0.058 & - \\
\hline \multicolumn{9}{|l|}{ Water vapour resistance } \\
\hline factor & - & 13.2 & 30 & 12 & 1 & 10 & 40 & 0.2 \\
\hline \multicolumn{9}{|l|}{ Liquid water conductivity at } \\
\hline saturation moisture content & $\mathrm{kg} /(\mathrm{m} \cdot \mathrm{s} \cdot \mathrm{Pa})$ & $1.4 \cdot 10^{-8}$ & $6.5 \cdot 10^{-10}$ & $2.8 \cdot 10^{-9}$ & - & $6.3 \cdot 10^{-9}$ & $4.0 \cdot 10^{-9}$ & - \\
\hline
\end{tabular}

\subsubsection{Boundary conditions}

Interior and exterior boundary conditions were applied in the model. The measured indoor temperature and relative humidity were applied when validating the model, and a constant temperature of $20^{\circ} \mathrm{C}$ and a relative humidity of $\mathrm{RH}=50 \%$ were applied when simulating worst-case scenarios. The exterior environment was simulated with real weather data measured, provided by the Danish Meteorological Institute (DMI) when validating the model. The simulations performed for worst-case scenarios were simulated with the Design Reference Year (DRY) for Denmark. The boundary conditions for the interior and exterior environment are listed in Table 2. The thermal heat transfer coefficients for surface heat flow 
were: inside: $10 \mathrm{~W} /\left(\mathrm{m}^{2} \mathrm{~K}\right)$ (upwards), $6 \mathrm{~W} /\left(\mathrm{m}^{2} \mathrm{~K}\right)$ (downwards), $8 \mathrm{~W} /\left(\mathrm{m}^{2} \mathrm{~K}\right)$ (horizontal), and outside: 25 $\mathrm{W} /\left(\mathrm{m}^{2} \mathrm{~K}\right)$. The vapour diffusion coefficients were $3 \cdot 10^{-8} \mathrm{~kg} /\left(\mathrm{m}^{2} \cdot \mathrm{s} \cdot \mathrm{Pa}\right)$ for the interior and $8 \cdot$ $10^{-8} \mathrm{~kg} /\left(\mathrm{m}^{2} \cdot \mathrm{s} \cdot \mathrm{Pa}\right)$ for the exterior. The initial conditions for the hygrothermal simulation consisted in a temperature of $15^{\circ} \mathrm{C}$ and a relative humidity of $65 \%$.

Table 2: Boundary conditions for the interior and exterior environment for a) the validation of the model and b) the worst-case modelling. (DMI=Danish Meteorological Institute, DRY= Design Reference Year).

\begin{tabular}{|c|c|c|c|}
\hline \multirow{2}{*}{ Boundary conditions } & \multirow{2}{*}{ Climate files } & \multicolumn{2}{|c|}{ Source } \\
\hline & & $\begin{array}{l}\text { Validation of } \\
\text { model }\end{array}$ & $\begin{array}{l}\text { Worst-case } \\
\text { modelling }\end{array}$ \\
\hline \multicolumn{4}{|l|}{ Inside } \\
\hline Heat conduction & Air temperature $\left[{ }^{\circ} \mathrm{C}\right]$ & $\begin{array}{l}\text { Measurements in } \\
\text { test building: data } \\
\text { points }\end{array}$ & $\begin{array}{l}\text { Constant } \\
\text { value: } \\
\mathrm{T}=20^{\circ} \mathrm{C}\end{array}$ \\
\hline \multirow[t]{2}{*}{ Vapour diffusion } & Air temperature $\left[{ }^{\circ} \mathrm{C}\right]$ & Measurements in & Constant \\
\hline & Relative Humidity [\%] & $\begin{array}{l}\text { test building: data } \\
\text { points }\end{array}$ & $\begin{array}{l}\text { value: } \\
\mathrm{T}=20^{\circ} \mathrm{C}, \\
\mathrm{RH}=50 \%\end{array}$ \\
\hline \multicolumn{4}{|l|}{ Outside } \\
\hline \multirow[t]{2}{*}{ Heat conduction } & Air temperature $\left[{ }^{\circ} \mathrm{C}\right]$ & Measurements & DRY file for \\
\hline & & DMI: data points & Denmark \\
\hline \multirow[t]{2}{*}{ Vapour diffusion } & Air temperature $\left[{ }^{\circ} \mathrm{C}\right]$ & Measurements & DRY file for \\
\hline & Relative Humidity [\%] & DMI: data points & Denmark \\
\hline \multirow[t]{5}{*}{ Wind-driven rain } & Horizontal Rain $\left[\mathrm{l} /\left(\mathrm{m}^{2} \mathrm{~h}\right)\right]$ & Measurements & DRY file for \\
\hline & Wind direction $\left[{ }^{\circ}\right]$ & DMI: data points & Denmark \\
\hline & Wind velocity $[\mathrm{m} / \mathrm{s}]$ & & \\
\hline & Air temperature $\left[{ }^{\circ} \mathrm{C}\right]$ & & \\
\hline & Relative Humidity [\%] & & \\
\hline \multirow[t]{2}{*}{ Short wave radiation } & Direct solar radiation [W/m²] & Measurements & DRY file for \\
\hline & Diffuse solar radiation $\left[\mathrm{W} / \mathrm{m}^{2}\right]$ & DMI: data points & Denmark \\
\hline Long wave radiation & Sky radiation $\left[\mathrm{W} / \mathrm{m}^{2}\right]$ & Measurements & DRY file for \\
\hline
\end{tabular}




\subsubsection{Determination of Catch Ratio (CR)}

The rain striking the façade can be expressed by rain intensity vectors, which are also described as the catch ratio or the rain exposure coefficient (Nicolai and Grunewald, 2005-2006 [26]; Blocken and Carmeliet, 2002[27]):

$$
C R(t)=\frac{R_{d r}(t)}{R_{h}(t)}
$$
$C R(t) \quad$ Catch ratio
$R_{d r}(t) \quad$ Driven rain intensity (integrated over all raindrop diameters)
$R_{h}(t) \quad$ Unobstructed horizontal rainfall intensity (integrated over all raindrop diameters)

Kragh (1998, chapter 6) [28] studied the microclimate on a building in Denmark and measured the catch ratio for a west-orientated façade on a 3 storey building to be between $0.2-0.4$ depending on the location. The catch ratio was found to be higher for the corners and for the edges than for the middle of the building. Furthermore, they found the average wind velocity to be approximately $6 \mathrm{~m} / \mathrm{s}$ at a height of 10 m. Blocken and Carmeliet, (2006) [29] also studied the catch ratio for different building shapes using a CFD tool. According to them, the catch ratio for a building with dimensions (height $\mathrm{x}$ width $\mathrm{x}$ length= $20 \mathrm{~m} \times 10 \mathrm{~m} \times 100 \mathrm{~m}$ ) was found to vary from 0.2 in the middle of the building to 1.45 at upper corner when the wind velocity was $10 \mathrm{~m} / \mathrm{s}$. This shape and size could be comparable to the building shape of the multi storey test building. On the basis of the Design Reference Year (DRY) for Denmark, the average wind velocity is $4.36 \mathrm{~m} / \mathrm{s}$, which according to Blocken and Carmeliet, (2006) [29] corresponds to a catch ratio of approximately 0.5 based on CFD simulations. Blocken et al. (2011) [30] compared CFD simulations with measurements and the ISO-standard 15927-3:2009 (2009) [31] for determining the catch ratio of a façade, and they found that on average the catch ratio was $0.2-0.25$ for two low-rise buildings. 
These studies, however, represent the case with no obstacles to affect the catch ratio. Most multi-storey buildings, including the test building, are located in an urban area and the surroundings will affect the wind-driven rain. Coutu et al. (2013) [32] investigated wind-driven rain on façades in urban areas. They found that in urban areas the wind-driven rain on the façade is significantly less than in open areas, resulting in catch ratios ranging from 0.01-0.09, all much lower than what other literature suggests. Based on this, the catch ratio will probably not reach 0.5 in urban areas, but will more likely be 0.1 or less. But simulations were carried out with catch ratios of $\mathrm{CR}=0.1, \mathrm{CR}=0.3$ and $\mathrm{CR}=0.5$ in order to cover representative and worst-case scenarios.

\subsubsection{Validation of the model of the wooden floor beams}

Two models were created with wall thicknesses of 2 bricks and 1.5 bricks to represent the façade on the $4^{\text {th }}$ and $5^{\text {th }}$ floors respectively. The model was created with a gap in the insulation above the floor construction, as was done in the test building, to validate the simulation model of the beam construction with the measurements. The model was simulated for 1 year starting in June. The calculated temperature and relative humidity were compared with the measured data in the apartments in Copenhagen.

\subsubsection{Worst-case modelling}

The worst-case scenarios were simulated for 4 and 10 years starting in September for the wooden beam end and for the interface between the insulation and the brick wall, respectively. After validating the model of the wooden beam, various scenarios were simulated to find worst cases. Three scenarios of applying the insulation were modelled: Figure 3(a): insulation applied on the entire interior façade; Figure 3(b): a gap of $200 \mathrm{~mm}$ in the insulation above the floor; and Figure 3(c): a gap of $200 \mathrm{~mm}$ in the insulation both above the floor and below the ceiling. Reference models were also created to represent the conditions before the retrofitting. The 1D-model for the wall is shown in Figure 3(d). The models were simulated with the wall orientated towards the west and north. The most dominant wind-direction in 
Denmark is west (Cappelen and Jørgensen, 1999) [33], and west-orientated façades are therefore exposed to more wind-driven rain. But north-orientated façades will not have direct sun, which results in reduced drying potential. Both orientations are therefore of interest. Furthermore simulations were carried out for wall thicknesses of 1.5 and 2 bricks, and for insulation thicknesses of 40mm and 80mm.

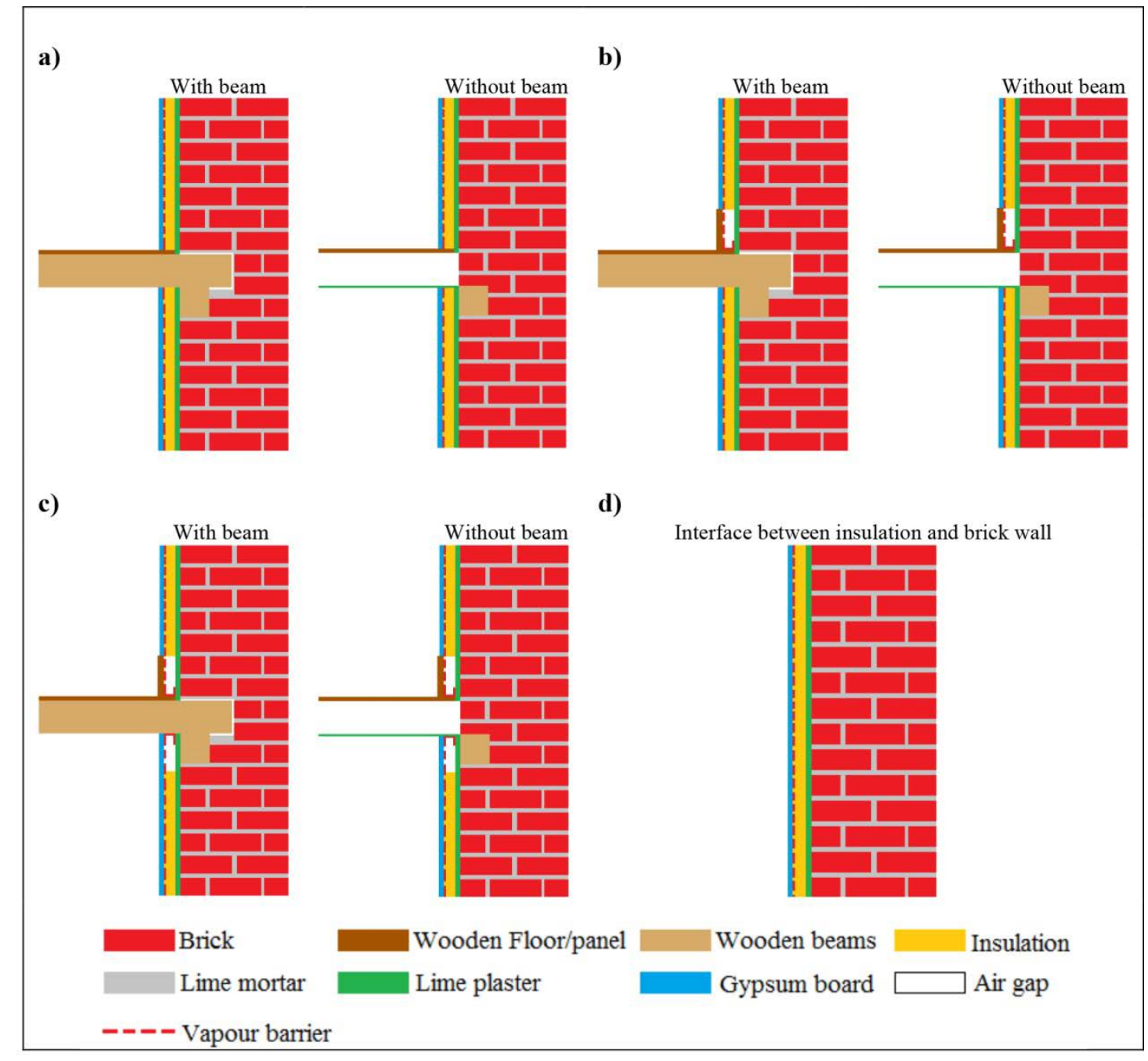

Figure 3: The various scenarios of internal insulation applied in the Delphin models - with and without the floor beam for a) full insulation on the entire interior façade; b) 200mm gap in the insulation above 
the floor; c) 200mm gap in the insulation above and below the floor/ceiling; d) 1D model of the wall with internal insulation.

\subsubsection{Evaluation of mould growth}

Hukka and Viitanen et al. (1999) [34] developed a mathematical model for evaluating the risk of mould growth on wood (the VTT-model), which has been further developed over the years and is described in several papers (Vereecken and Roels, 2012 [35]; Viitanen and Ojanen, 2007[36]; Viitanen, 1997 [12]; Ojanen et al., 2010 [37]). The model was developed based on tests and includes critical limits for relative humidity, temperature and the time factor, for conditions favourable and non-favourable for mould growth. A more recent study has further developed the model, so that it also includes other materials, such as concrete, cement, plastic-based materials, glass and metals (Ojanen et al., 2010 [37]). The model calculates the Mould Index (M), which describes the growth rate. The mould index can range from $M=0-6$ and is described in Table 3. The critical relative humidity in the model defines the minimum value at which mould growth can occur. The critical limit for mould growth on wood in the VTT-model is $80 \%$ and $85 \%$ for the interior surface of an exterior façade (Ojanen et al., 2010[37]). For a detailed description of the model, see Hukka and Viitanen et al. (1999) [34], Viitanen and Ojanen (2007) [36] and Ojanen et al. (2010) [37].

Table 3: Description of Mould Index (Viitanen and Ojanen, 2007[36]).

\begin{tabular}{ccc}
\hline Index & Growth rate & Description \\
\hline 0 & No growth & Spores not activated \\
1 & Small amount of mould on surface (microscope) & Initial stage of growth \\
2 & $<10 \%$ coverage of mould on surface (microscope) & - \\
3 & $10-30 \%$ coverage of mould growth on surface (visual) & New spores produced \\
4 & $30-70 \%$ coverage of mould growth on surface (visual) & Moderate growth \\
5 & $>70 \%$ coverage of mould growth on surface (visual) & Plenty of growth \\
6 & Very heavy and tight growth & Coverage around $100 \%$ \\
\hline
\end{tabular}




\section{Results and discussion}

\subsection{Measurements in the wooden beam ends and validation of the simulation model of the wooden}

beam construction.

The measurements of temperature and relative humidity monitored in the wooden floor beam ends are shown in Figure 4 for the $4^{\text {th }}$ floor ( 2 bricks) and the $5^{\text {th }}$ floor $(1.5$ bricks). The results from the simulation model with rain exposure coefficients of $\mathrm{CR}=0.1,0.3$ and 0.5 are shown together with the measured indoor temperature and relative humidity. As can be seen, the room measurements are missing for large periods for the $4^{\text {th }}$ floor ( 2 bricks). To provide input data to the simulation model from the measured indoor conditions, the temperature and relative humidity were assumed to be an average value of the two measured points before and after the lack of data. The results from the simulation model are therefore incorrect during these periods, which also explains the rather large deviation in the temperatures in Figure 4(a). However, the deviation is only $1-2^{\circ} \mathrm{C}$ for the remaining period, when the actual measured data was used. Moreover, the effect of the thinner wall is expressed by the lower temperature levels during wintertime, and there is good agreement between the measurements and the calculations. Greater deviations can be seen in the measured and the calculated relative humidity. The dynamics are greater in the measurements than in the simulation results. This can be explained by the mathematical model used in Delphin. Delphin only has a temperature-dependent sorption-isotherm for air, whereas for other materials it calculates the relative humidity based on the moisture content. The moisture content only changes based on moisture transport, which can be rather slow. Even though we have created a small air-space inside the wooden beam, it is still affected by the conditions in the wood, which might change slower than reality. However, the calculated relative humidity has the same levels as the measured, varying only by a few percentages. Another effect seen in Figures 4(c) and 4(d) is that the thinner the brick wall, the more 
variation occurs in relative humidity, which results in greater deviation between the measured and the calculated results.

The simulation models were calculated with various rain exposure coefficients. As seen in Figure 4, the changes in the rain exposure coefficient have no effect on the calculated temperatures and very limited effect on the calculated relative humidity. The main reason for this is that an air space is modelled between the brick wall and the wooden beam heads, resulting in a limited moisture transport from the exterior to the measuring point. This confirms that it is not possible to validate the part of the model that includes the brick wall because the measurements are most affected by the indoor environment and the outdoor temperature and less by the outdoor wind-driven rain.

Based on comparison between the measurements and calculations in the wooden beam ends, the model seems to provide good results in the periods when the indoor temperature and relative humidity measurements were available. 

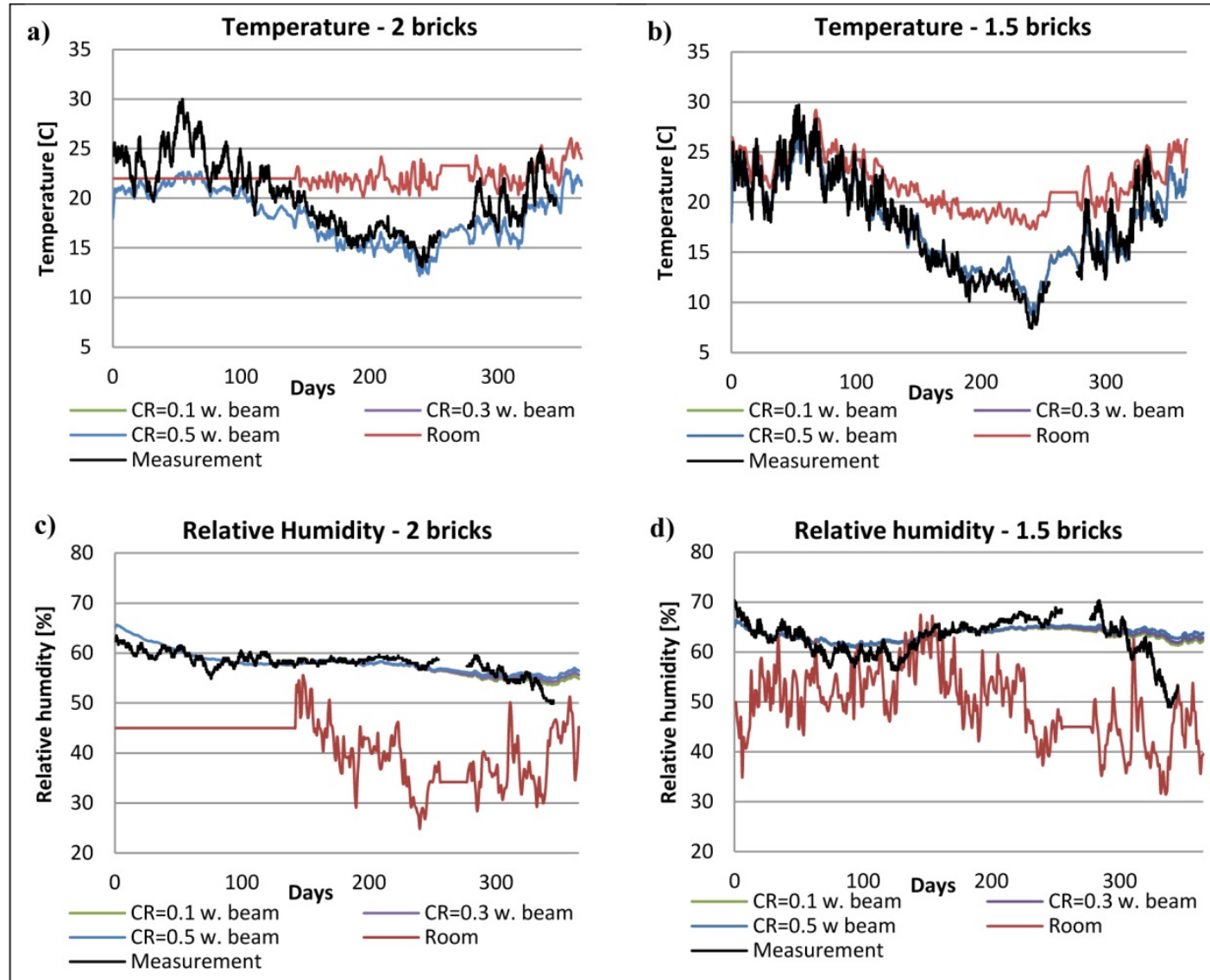

Figure 4: Temperatures and relative humidity in the wooden beam ends from measurements and simulations. The measured room temperature and relative humidity were used as input to the simulation model.

\subsection{Worst-case simulation with Delphin}

\subsubsection{Wooden beams}

The models were simulated with a wall thickness of 2 bricks and for orientations towards the west and the north for a period of 4 years. Figure 5(a) shows the mould growth index for a west-orientated façade and 
Figure 5(b) for a north-orientated façade in the wooden beam end (position 1). The simulations were carried out for rain exposure coefficients of $\mathrm{CR}=0.1, \mathrm{CR}=0.3$ and $\mathrm{CR}=0.5(\mathrm{CR}=0.5$ only for the westorientated wall) and for (i) no insulation (blue scale), (ii) insulation applied to the entire wall (red scale), (iii) insulation applied with a gap of 200mm above the floor (grey scale), and (iv) insulation applied with a gap of 200mm above and below the floor/ceiling (green scale). It is clear from Figure 5 that the northorientated façade results in higher mould indexes than the west-orientated façade for low rain exposure coefficients. Most of the scenarios show an increasing trend, implying that there will be an accumulation of mould growth over the years even if the growth stops or decreases during summertime. All rain exposure coefficients greater than $C R=0.1$ result in a high mould index (between $M=4$ and $M=6$ ) indicating visual mould covering between $30-100 \%$ of the surface. Only the north-orientated façade without insulation and a rain exposure coefficient of $\mathrm{CR}=0.1$ results in a mould index lower than 1 . For the west-orientated wall, the mould index is kept below $M=1$ when a gap of $200 \mathrm{~mm}$ is applied in the insulation above the floor and when it is applied both above and below the floor/ceiling. The last case results in more secure conditions, since the mould index decreases to $M=0$ each year, whereas if a gap in the insulation is only applied above the floor, a small increasing trend is observed. However, it should be kept in mind that the floor beam is modelled as a continuous beam, whereas in reality there is a beam only approximately every 1 metre. The results are therefore on the conservative side. Figure 5 shows that the gap in the insulation has a positive effect on the moisture conditions in the beam end and reduces the mould index in all cases. However, there is still a large risk of mould growth in the beam end. 


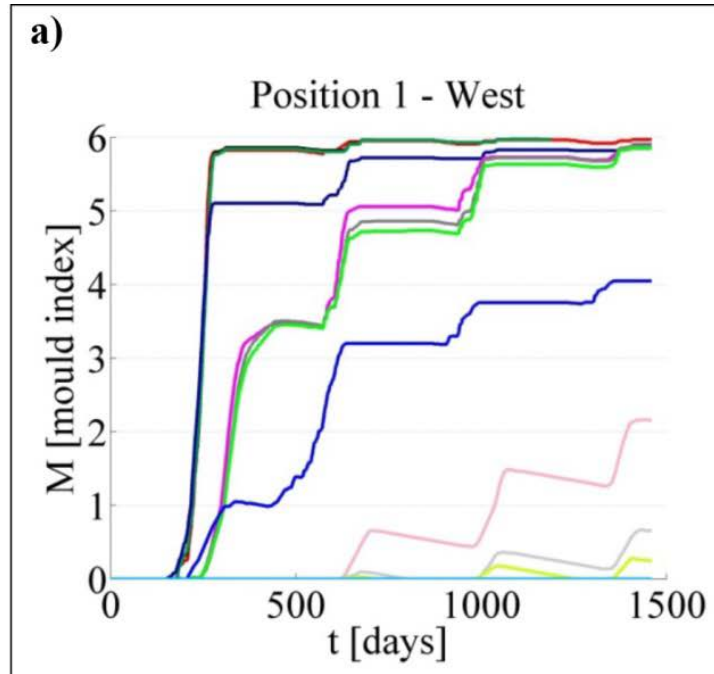

-Full insulation $(\mathrm{CR}=0.5)$

$-200 \mathrm{~mm}$ gap - above $(\mathrm{CR}=0.5)$

$-200 \mathrm{~mm}$ gap - above - below $(\mathrm{CR}=0.5)$

-No insulation $(\mathrm{CR}=0.5)$

-Full insulation $(\mathrm{CR}=0.3)$

$-200 \mathrm{~mm}$ gap - above $(\mathrm{CR}=0.3)$

$-200 \mathrm{~mm}$ gap - above - below $(\mathrm{CR}=0.3)$

-No insulation $(\mathrm{CR}=0.3)$

-Full insulation $(\mathrm{CR}=0.1)$

-200mm gap - above $(\mathrm{CR}=0.1)$

$200 \mathrm{~mm}$ gap - above - below $(\mathrm{CR}=0.1)$

-No insulation $(\mathrm{CR}=0.1)$

b)

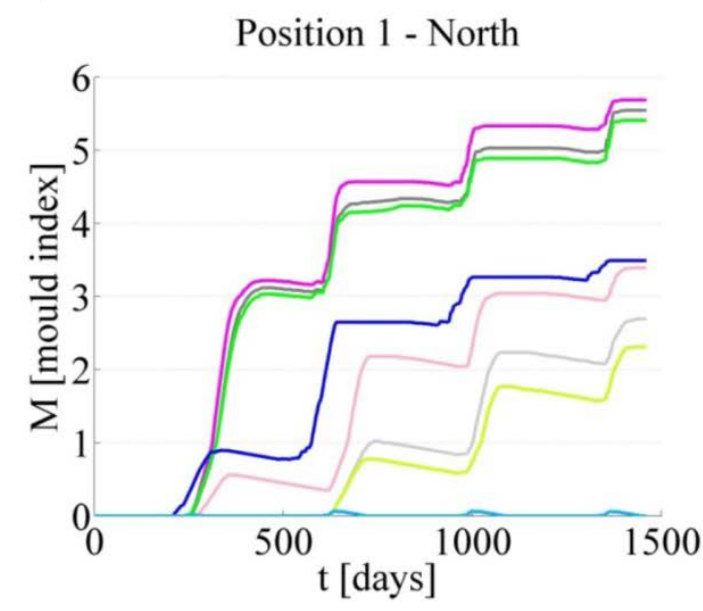

-Full insulation $(\mathrm{CR}=0.3)$

$-200 \mathrm{~mm}$ gap - above $(\mathrm{CR}=0.3)$

$-200 \mathrm{~mm}$ gap - above - below $(\mathrm{CR}=0.3)$

-No insulation $(\mathrm{CR}=0.3)$

-Full insulation $(\mathrm{CR}=0.1)$

200mm gap - above $(\mathrm{CR}=0.1)$

$200 \mathrm{~mm}$ gap - above - below $(\mathrm{CR}=0.1)$

-No insulation $(\mathrm{CR}=0.1)$

Figure 5: Mould index in position 1 for a) west- and b) north-orientated façades - 2 bricks thick. $C R=0.1$, 0.3, 0.5. No insulation; with internal insulation on the entire wall; with a gap of $200 \mathrm{~mm}$ in the insulation above the floor; and with a gap of 200mm in the insulation above and below the floor/ceiling.

Figure 6 shows the mould index in position 2 for a west-orientated façade (a) with and (b) without the floor beam perpendicular to the façade. The simulations without the floor beams result in lower mould 
indexes, due to a better drying possibility. As mentioned above, the simulations with the floor beams do not represent reality completely since they are modelled as a continuous beam due to the 2D model.

Therefore the real results will be somewhere between the results from Figures 6(a) and (b). The results are similar in position 2 to those in position 1 for the west-orientated façade. When the rain exposure coefficient is $\mathrm{CR}=0.1$, the mould index is below $\mathrm{M}=1$ for the two insulation solutions with a $200 \mathrm{~mm}$ gap applied. However, when the gap is only applied above the floor, an increasing trend is observed, which is not the case when the gap is applied both above and below the floor/ceiling. Figure 6(b) (without the beam) shows that there is no risk of mould growth for any case when the rain exposure coefficient is $\mathrm{CR}=0.1$. The effect of the gap in the insulation is clear and gives lower mould indexes than a fully insulated wall. The figure shows that when the rain exposure coefficient is $\mathrm{CR}=0.5$, there is even a heavy mould growth for an uninsulated wall. It is known that many buildings have or have had mould problems even without internal insulation, and higher rain exposure coefficients may therefore be realistic in some cases. However, when the rain exposure coefficient is $\mathrm{CR}=0.5$, the results show that all wooden surfaces should be completely covered with mould even without insulation, which is not the case. It is therefore believed that the rain exposure coefficient is less than $\mathrm{CR}=0.5$. 


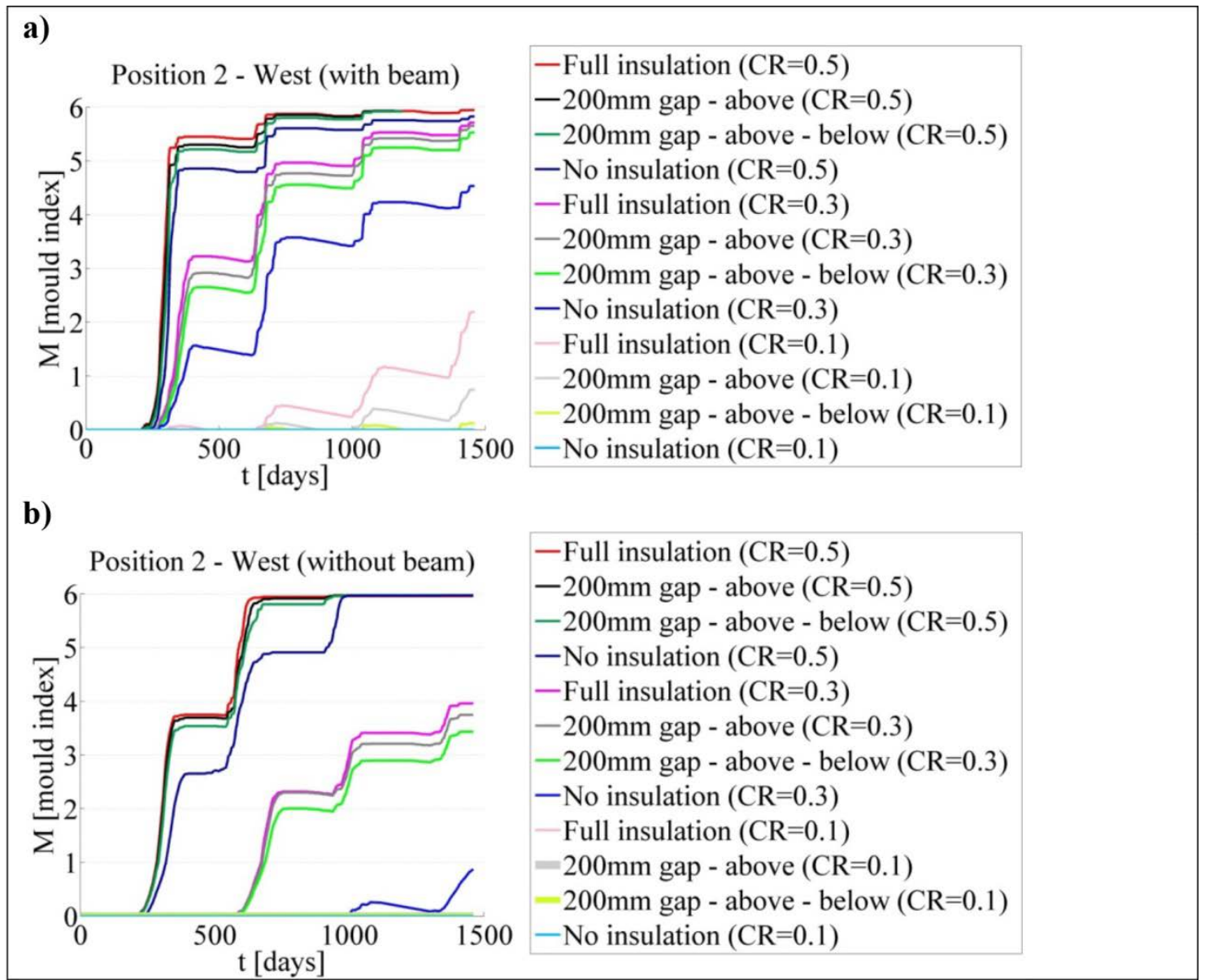

Figure 6: Mould index in position 2 for a west-orientated façade - 2 bricks thick, a) with and b) without the floor beam for $C R=0.1,0.3,0.5$ and for no insulation; with internal insulation on the entire wall; with a gap of 200mm in the insulation above the floor; and with a gap of 200mm in the insulation above and below the floor/ceiling.

Figure 7 shows the mould index in position 2 for a north-orientated wall 2 bricks thick (a) with and (b) without the floor beam. In general, the north-orientated façade has higher mould indexes than the westorientated façade for low rain exposure coefficients and for the case where the beam is modelled. The reason can be that the drying potential is significantly reduced. Figure 7(a) (with the floor beam) shows 
higher mould indexes than Figure 7(b) (without the floor beam) since the drying potential is reduced when the floor beam is modelled. As seen from Figure 7(a), none of the solutions seems to be safe. Even at low rain exposure coefficients and with a gap in the insulation both above and below the floor/ceiling, an increasing mould index reaches $\mathrm{M}=2$ after 4 years. A mould index of 2 still represents a very limited mould growth at a microscopic level. However, the trend is strongly increasing and if the simulations were to be carried out for more years, they would probably result in much higher levels. In contrast, Figure 7(b) shows that there is no risk of mould growth for any case with a rain exposure coefficient of $\mathrm{CR}=0.1$, even when the wall is fully insulated. For rain exposures of $\mathrm{CR}=0.3$, the mould index reaches $M=2.5-3$ when there is a gap applied in the insulation, but a small increasing trend is observed. The mould indexes will be lower in reality than the results shown in Figure 7(a), since they will have the possibility to dry out between the floor beams. The case where a 200mm gap is applied in the insulation above and below the ceiling may therefore be a safe solution if there is enough drying potential to the sides of the beam. 


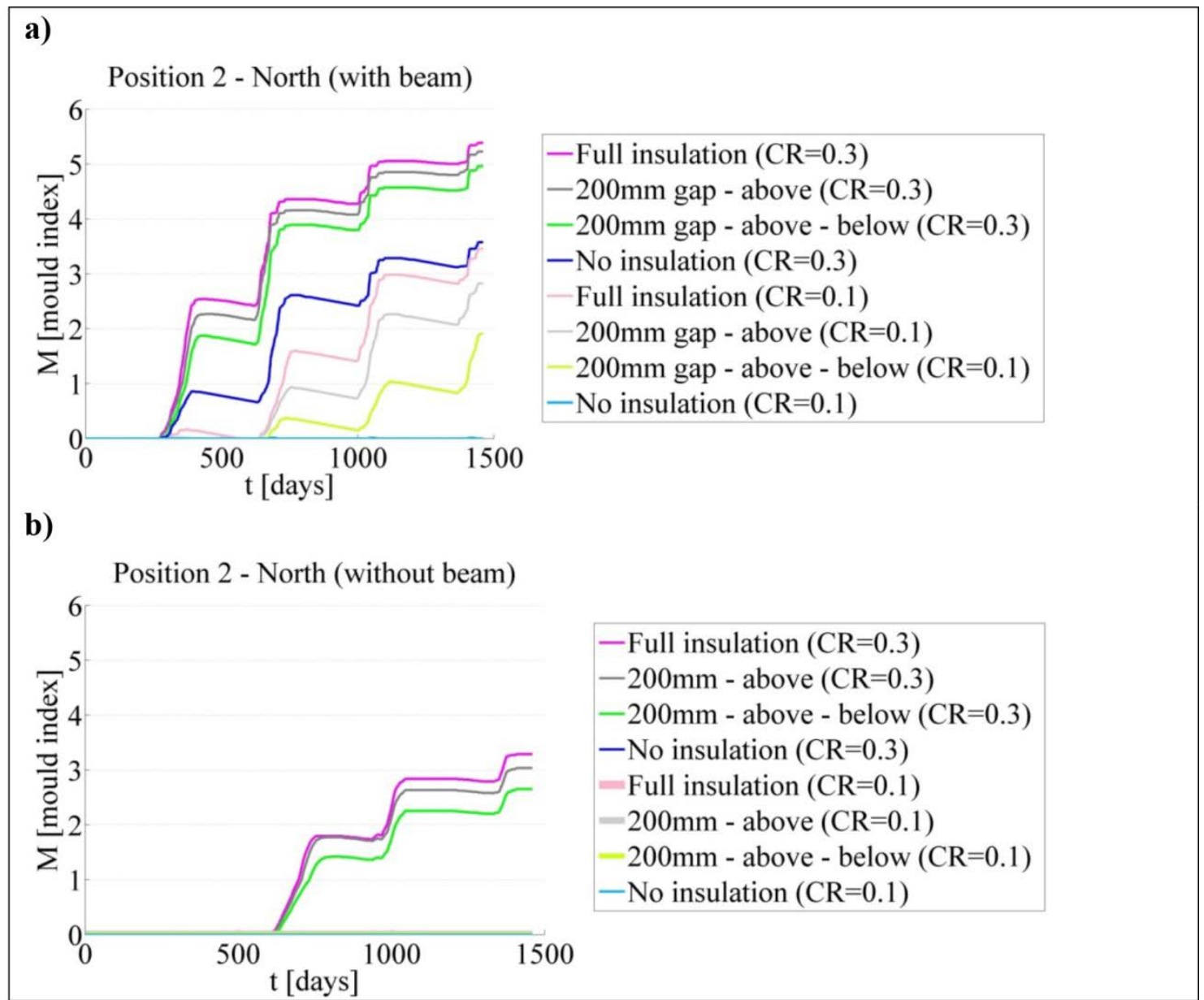

Figure 7: Mould index in position 2 for a north-orientated façade - 2 bricks thick, a) with and b) without the floor beam for $C R=0.1,0.3,0.5$ and for no insulation; with internal insulation on the entire wall; with a gap of 200mm in the insulation above the floor; and with a gap of 200mm in the insulation above and below the floor/ceiling.

Figure 8 shows the temperature and relative humidity fields for the construction with the different insulation solutions and for an uninsulated wall. The figure shows the sections at the beam end and between the beams, referred to as with beam and without beam respectively. The figure shows higher temperatures around the wooden beams are seen as a result of the $200 \mathrm{~mm}$ gap in the insulation with the 
greatest effect when gap in the insulation is both above and below the floor/ceiling. The higher temperatures result in lower relative humidity and therefore a decreased risk of mould growth.

Temperatures are higher in the section plane between the beams (without the beam) than where the beam is located (with the beam), resulting in lower relative humidity. The drying potential between the beams is therefore higher, which is in good agreement with the results from the mould risk analyses. The figure shows that when the internal wall is fully insulated the wooden construction has a relative humidity above 80-90\% in the outer part of the floor beam and at the load-bearing beam, whereas the relative humidity drops to below $80 \%$ for most of the wooden construction when there is a gap in the insulation both above and below the floor/ceiling. When there is a gap in the insulation, one might expect a risk of mould growth and condensation on the part of the wall that is uninsulated behind the panel. However, a vapour barrier was applied in accordance with Figure 3, which prevented the moist room air reaching the wall surface and condensing if the temperature is low enough. The temperature on the uninsulated wall behind the panel is around $9-10^{\circ} \mathrm{C}$ with the floor beam and $12-15^{\circ} \mathrm{C}$ without the beam. For a room temperature of $20^{\circ} \mathrm{C}$ and a relative humidity of $50 \%$, the dew-point is $9^{\circ} \mathrm{C}$ and there would be a risk of condensation if the construction is not vapour tight. Therefore it is crucial that the vapour barrier is applied correctly. Another issue that could arise when there are gaps in the insulation in some parts of the wall is the phenomenon of ghosting marks, which are dust particles trapped on the cold part of a surface. According to Christensen and Koch (2012) [38], this can happen when the temperature difference on a surface is greater than $2-3^{\circ} \mathrm{C}$. Figure 8 shows that the temperature difference between the panel and the insulated wall is around $3^{\circ} \mathrm{C}$ for the section plane with the beam and around $1-2^{\circ} \mathrm{C}$ for the section plane between the beams. A risk of ghosting marks is therefore present at the panel over the floor beams. However, again it should be kept in mind that the simulation model is a 2D model and the temperature difference is on the conservative side. 


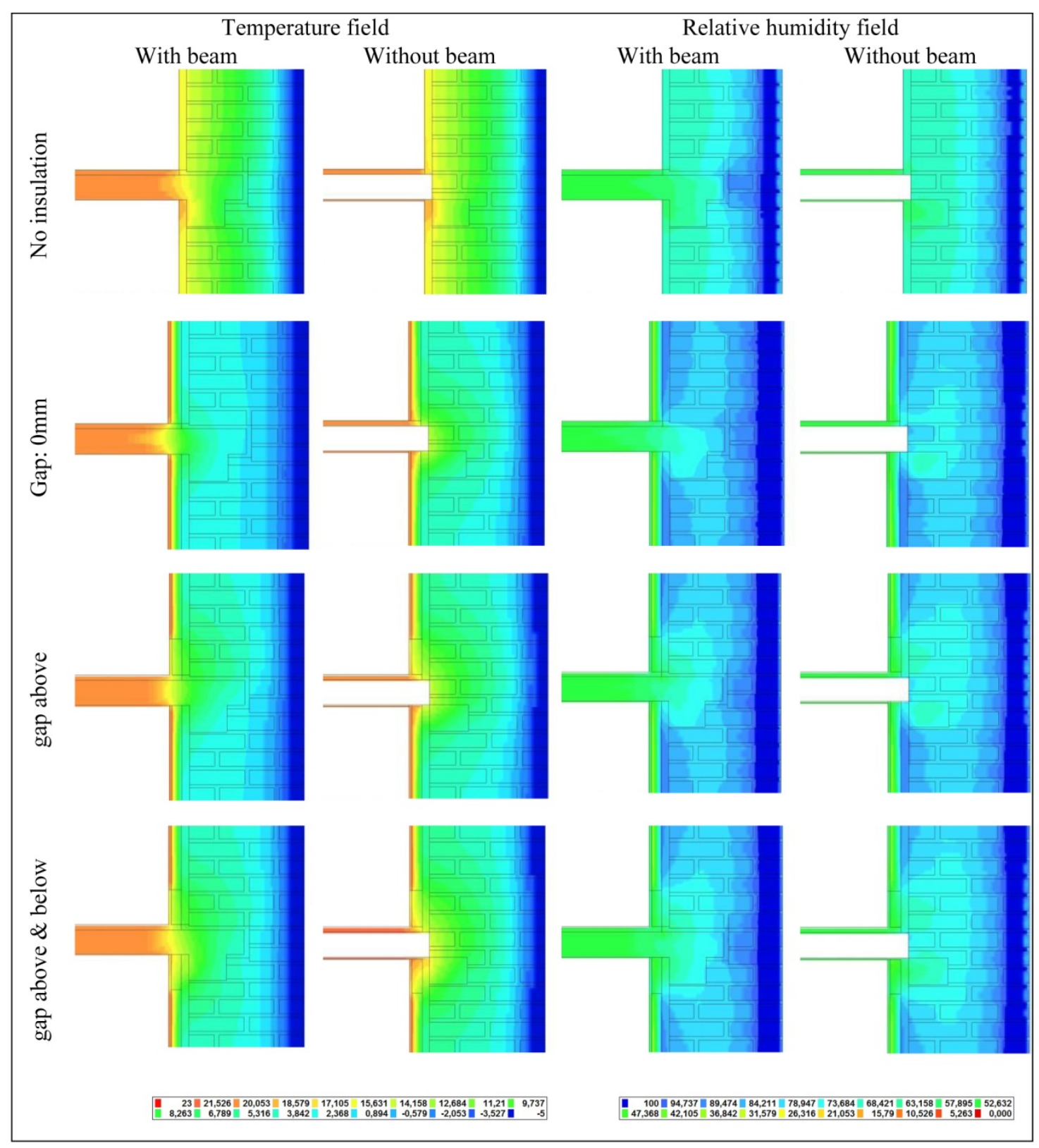

Figure 8: Temperature and relative humidity fields for the models with and without the wooden floor beam and for the four cases with no insulation, insulation on the entire wall, insulation applied with a 
$200 \mathrm{~mm}$ gap over the floor, and insulation applied with a gap of 200mm above and below the floor/ceiling.

Figure 9 shows the mould index for the solution with a gap of 200mm above and below the floor/ceiling with 40mm and 80mm of insulation respectively. As shown in Figure 9, the increased insulation thickness increases the mould growth index slightly. The effect of the extra insulation is not that significant since there is a gap in the insulation above and below the floor/ceiling and the beam construction is therefore less affected. However, the mould indexes increased compared to $40 \mathrm{~mm}$ insulation, and it seems to be safe to apply 80mm insulation only for low rain exposure coefficients for position 2 without the floor beam. Therefore, since even using 40mm insulation already shows debatable results, it cannot be recommended to apply more insulation and lower thermal transmittances of the wall. 


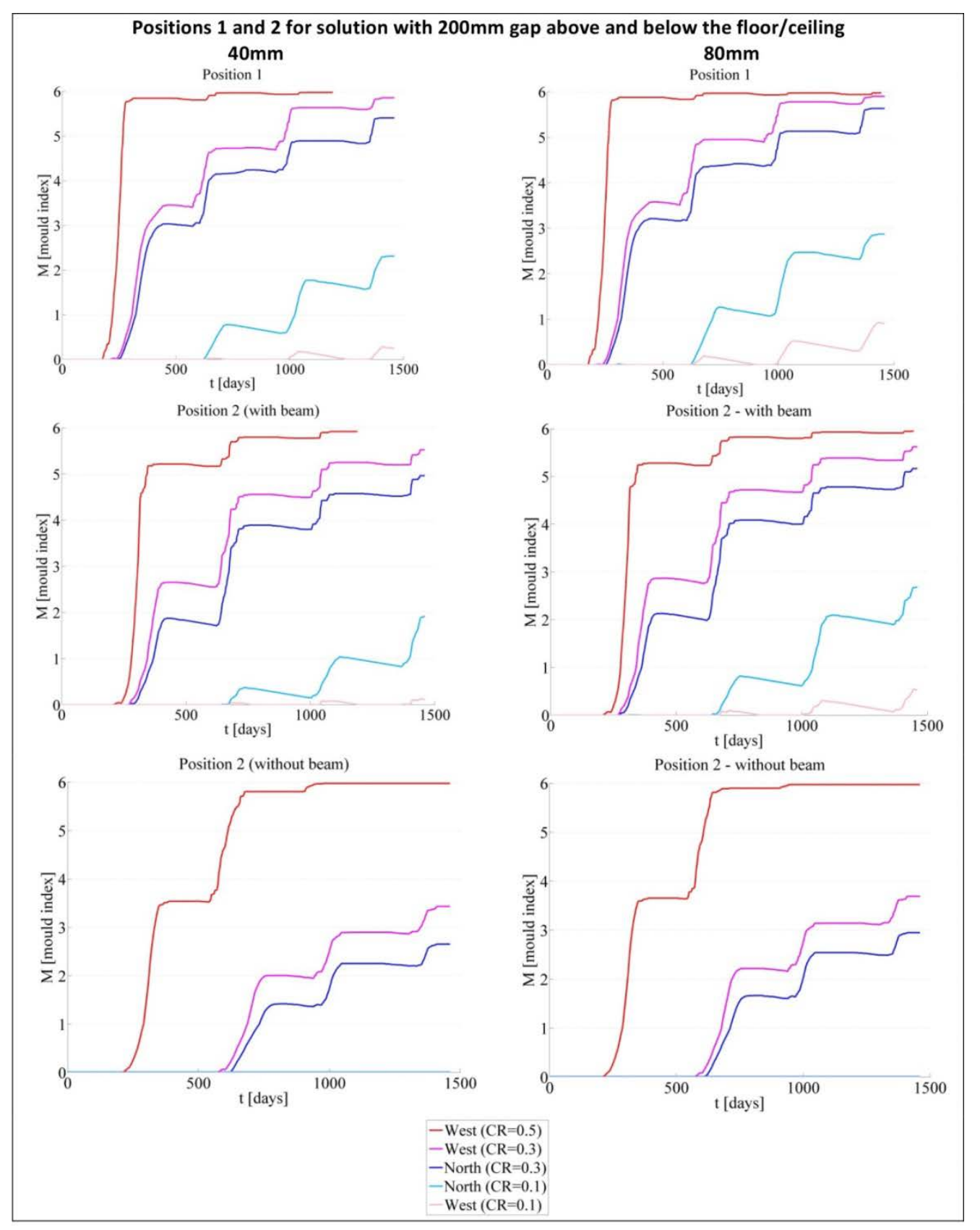

Figure 9: 40mm and 80mm insulation applied on the wall. Mould index in positions 1 and 2 for the solution with a gap of 200mm above and below the floor/ceiling. 


\subsubsection{Interface between the insulation and the brick wall}

Figure 10 shows the mould index in the interface between the insulation and the brick wall (position 3) with $40 \mathrm{~mm}$ and $80 \mathrm{~mm}$ insulation applied. Simulations were performed for four cases; for west- and north-orientated walls and for wall thicknesses of 1.5 and 2 bricks in both cases. The maximum mould index in all cases was approximately 3.5, corresponding to a visual coverage of mould growth of $10-30 \%$ on the surface. It can be seen that for a north-orientated wall the mould index increases faster and that for lower rain exposure coefficients the mould index reaches higher levels. Even with a rain exposure coefficient of $\mathrm{CR}=0.1$, the mould index reaches approximately $\mathrm{M}=2.5$, which is just below the visual mould growth state. Figure 10 also shows that a thinner wall results in a slightly higher risk of mould growth since it is more affected by driven rain. When $80 \mathrm{~mm}$ insulation is applied it can be seen that even with low rain exposures $(\mathrm{CR}=0.1)$ there is a risk of mould growth $(2<\mathrm{M}<3)$. For walls insulated with $40 \mathrm{~mm}$ insulation and with a low rain exposure coefficient $(\mathrm{CR} \leq 1)$, the west-orientated wall has no risk of mould growth, whereas the north-orientated wall has a significant risk of mould growth. Internal insulation might therefore be durable only with $40 \mathrm{~mm}$ insulation applied and for west-orientated walls. Extra caution needs to be taken if the wall is orientated towards the north and it is not recommended to apply more than $40 \mathrm{~mm}$ insulation. 


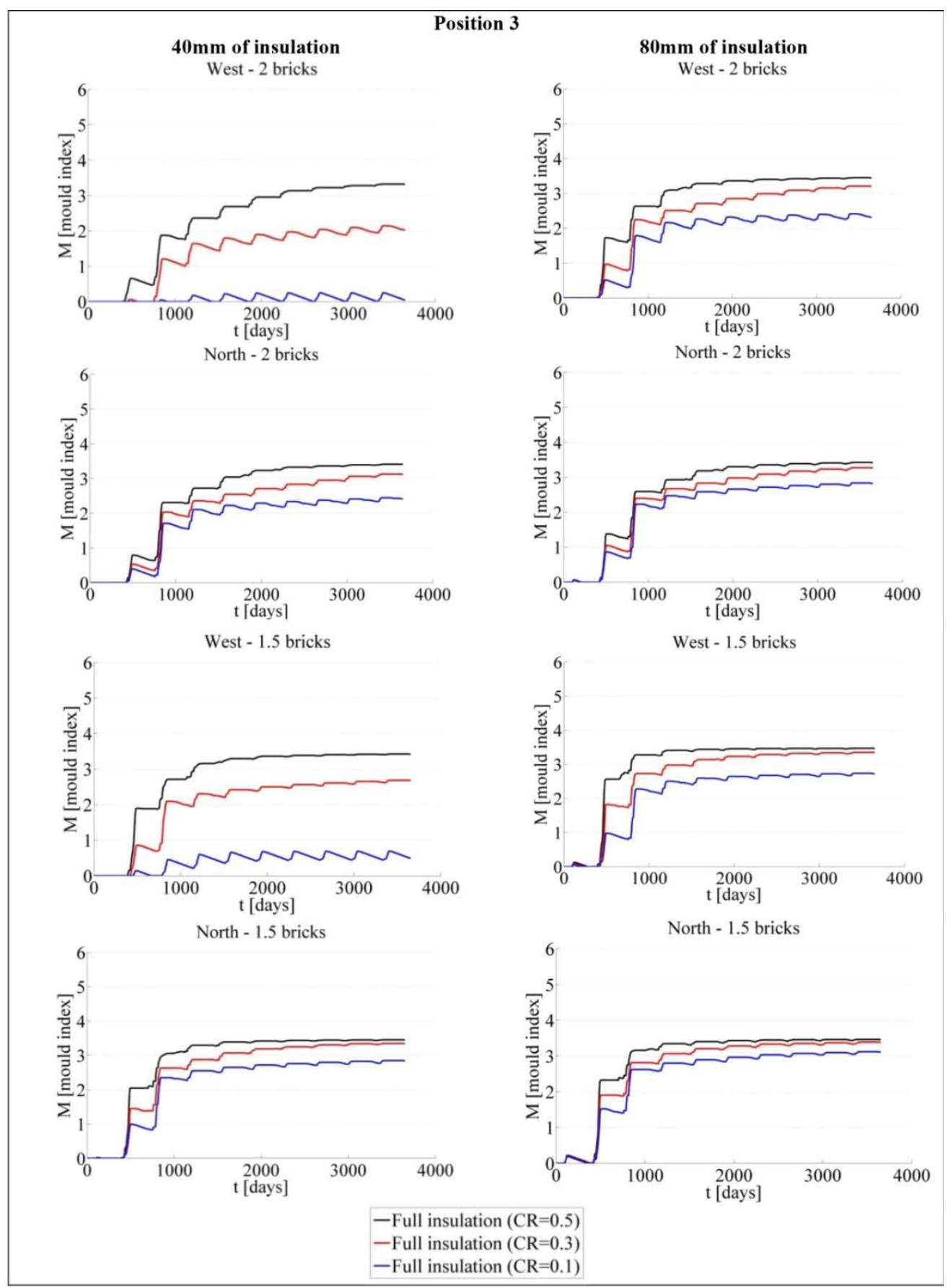

Figure 10: Mould index in position 3 for a west- and a north-orientated wall with a thickness of 1.5 and 2 bricks, and $40 \mathrm{~mm}$ and $80 \mathrm{~mm}$ insulation applied. RHcrit=85\%. 


\subsubsection{Risk of mould growth}

Based on these analyses, there is a large risk of mould growth on the wooden beam construction and behind the insulation when internal insulating is applied. However, the internal insulation product investigated was a mix of mineral wool and aerogel with a vapour barrier applied, and there is need for future research into using other innovative materials, such as capillary active and diffuse open material without vapour barrier. The simulation was created as a 2D model even though the real problem is a 3D problem, so uncertainties are involved in the results. The investigation was carried out based on two model types (with and without the beam), and the correct results will lie somewhere between the results from these two models. The models did not include any cracks, which could potentially lead to higher moisture content in the wall and consequently a higher risk of mould growth. This too needs future research. One possibility might be to reduce the amount of rain absorbed by the façade by impregnating the façade with a waterproof but diffuse open coating so moisture will not get trapped inside the brick wall. Another issue that needs to be addressed and investigated is to what extent we can accept mould that does not create a health risk. It might be acceptable to have some small amounts of mould, but this is an area that needs more investigation. The conclusions drawn in this paper are therefore based on the view that no mould growth is acceptable.

\section{Conclusion}

This paper presents an investigation of a method of applying internal insulation in a heritage multi-storey building. Measurements were carried out in the wooden beam ends in two test apartments on the $4^{\text {th }}$ and $5^{\text {th }}$ floors respectively. A hygrothermal 2D-simulation model created using Delphin was validated with measurements taken in the wooden floor beams of a test building to simulate worst-case scenarios with wall orientations towards the west and north. Furthermore, a 1D-model was created to simulate worst- 
case scenarios for the interface between the insulation and the wall. Three different insulation strategies were investigated to evaluate the risk of mould growth in the wooden beam-ends. It was found that the risk of mould growth could be reduced by applying a gap in the insulation above and below the floor/ceiling. However, moisture safety depends on other parameters, such as the orientation and rain exposure of the façade. While no risk of mould growth was found for a west-orientated façade with low rain exposure coefficients $(\mathrm{CR}=0.1)$ for position 1 and 2, heavy mould growth were detected for rain exposure coefficients higher than $\mathrm{CR}=0.1$. When the wall is orientated towards the north, the drying potential is reduced since no sun reaches the façade and the risk of mould growth increases significantly compared to the west-orientated wall.

The risk of mould growth in the interface between the insulation and wall was higher for a northorientated wall and for the thinner wall (1.5 bricks compared to 2 bricks). The maximum mould index reached 3.5, which corresponds to visual growth covering between $10-30 \%$ of the surface. But for a west orientated façade with low rain exposure coefficients, there was no risk of mould growth.

It is crucial to apply the vapour barrier correctly to prevent the moist room air reaching the façade. The uninsulated part of the wall (behind the 200mm gaps in insulation) will risk condensation and mould growth if the moist air reaches the façade, since this part of the wall will be close to the dew-point temperature for room air. Moreover, the phenomena of ghosting marks can occur if the temperature difference between the interior surface of the insulated wall and the uninsulated wall is greater than 2$3^{\circ} \mathrm{C}$, though this needs future research.

Due to the uncertainty of the actual rain exposure on the façade, further research is needed to draw final conclusions from the results. But when the coefficient is $C R \leq 0.1$ and the wall is orientated towards the west, the solution with a gap above and below the floor/ceiling seems to be moisture-safe. It is not recommended to apply $80 \mathrm{~mm}$ insulation, but to keep it to a maximum of $40 \mathrm{~mm}$. However, based on the 
results from this investigation it not recommended to apply internal insulation to a north-orientated wall with a thickness of 1.5 or 2 bricks, and caution should be exercised when it is applied to a west-orientated wall. This paper only investigated 1.5 and 2 brick walls. Internal insulation applied on thicker walls (2.53.5 bricks) might show different results.

\section{Acknowledgement}

The research presented in this paper was financed by the Danish Energy Agency under the Energy Technology Development and Demonstration Programme (EUDP) in the project entitled: "Udvikling og 1:1-demonstration af koncepter til renovering af ældre etageboliger til lavenergiklasse 1” (in Danish) (64009-0233) and under the project entitled: “Energirigtig comfort i ældre etageboliger” (in Danish) (64013-0574). The project teams consist of DTU Civil Engineering, COWI, Rönby.dk, Ecolab and Dresden University. Weather data for the simulation models was provided by the Danish Meteorological Institute.

\section{References}

[1] Engelmark J. Københavns Etageboligbyggeri 1850-1900, En Byggeteknisk Undersøgelse, Hørsholm, Danish Building Research Institute (in Danish); 1983.

[2] Rasmussen TV. Retrofitting Listed Buildings: Measures, Savings and Requirements. The Open Construction and Building Technology Journal, 2011;5:174-181.

[3] Straube J, Schumacher C. BSD-114: Interior Insulation Retrofits of Load-Bearing Masonry Walls In Cold Climates, Building Science Digests; 2007. 
[4] Christensen G, Bunch-Nielsen T. Indvendig efterisolering af ældre ydermure (BYG-ERFA erfaringsblad (31) 0910 29). Ballerup: BYG-ERFA (in Danish); 2009.

[5] Munch-Andersen J. SBi-Anvisning 221, Efterisolering af etageboliger, Hørsholm, Danish Building Research Institute, Aalborg University (in Danish); 2008.

[6] Kolaitis DI, Malliotakis E, Kontogeorgos DA, Mandilaris I, Katsourinis DI, Founti MA. Comparative assessment of internal and external thermal insulation systems for energy efficient retrofitting of residential buildings, Energy and Buildings, 2013;64:123-131.

[7] Abuku M, Janssen H, Roels S. Impact of wind-driven rain on historic brick wall buildings in moderately cold and humid climate: numerical analyses of mould growth risk, indoor climate and energy consumption, Energy and Buildings 2009;41:101-110.

[8] Krebs HJ, Collet PF. Indvendig Efterisolering: Indmurede Bjælkeenders Fugt 2 Og Temperaturforhold i Etagekryds. 1st ed. Tåstrup: Danish Technological Institute (in Danish), 1981.

[9] Kehl D, Ruisinger U, Plagge R, Grunewald J. Wooden Beam Ends in Masonry with Interior Insulation - A Literature Review and Simulation on Causes and Assessment of Decay, 2nd Central European Symposium on Building Physics, Vienna; 2013.

[10] Ruisinger U. Long-term measurements and simulations of five internal insulation systems and their impact on wooden beam heads, 2nd Central European Symposium on Building Physics, Vienna; 2013.

[11] Morelli M, Svendsen S. Investigation of interior post-insulated masonry walls with wooden beam ends, Journal of Building Physics, 2012; 36(3): 265-293.

[12] Viitanen HA. Modelling the time factor in the development of mould fungi - The effect of critical humidity and temperature conditions on pine and spruce sapwood, Holzforschung- International Journal of the Biology, Chemistry, Physics and Technology of Wood, 1997;51:6-14. 
[13] Viitanen H, Vinha J, Salmien K, Ojanen T, Peuhkuri R, Paajanen L, Lähdesmäki K. Moisture and Bio-deterioration Risk of Building Materials and Structures. Journal of Building Physics, 2008;33 (3). DOI: $10.1177 / 1744259109343511$.

[14] Sedlbauer K. Prediction of mould fungus formation on the surface of and inside building components, Dissertation, Figure 9, Fraunhofer Institute for Building Physics, Stuttgart University; 2001.

[15] Johansson P, Ekstrand-Tobin A, Svensson T, Bok G. Laboratory study to determine the critical moisture level for mould growth on building materials, International Biodeterioration \& Biodegradation, 2012;73:23-32.

[16] Nielsen KF, Holm G, Uttrup LP, Nielsen PA. Mould growth on building materials under low water activities. Influence of humidity and temperature on fungal growth and secondary metabolism, International Biodeterioration \& Biodegradation, 2004;54:325-336.

[17] Grant C, Hunter CA, Flannigan B, Bravery AF. The Moisture Requirements of Moulds Isolated from Domestic Dwellings, International Biodeterioration, 1989;25:259-284.

[18] Johansson P, Svensson T, Ekstrand-Tobin A. Validation of critical moisture conditions for mould growth on building materials, Building and Environment, 2013;62:201-209.

[19] Sedlbauer K. Prediction of mould growth by hygrothermal calculation. Journal of Building Physics, 2002;25(4): 321-336.

[20] Morelli M. Development of a method for holistic energy renovation, PhD-thesis - Chapter 5.2.2, Technical University of Denmark, Department of Civil Engineering, Report: BYG R-281, ISBN: 978877877366, ISSN: 1601-2917; 2014. 
[21] Johansson P, Geving S, Hagentoft CE, Jelle BP, Rognvik E, Kalagasidis AS, Time B. Interior insulation retrofit of a historical brick wall using vacuum insulation panels: Hygrothermal numerical simulations and laboratory investigations, Building and Environment, 2014;79:31-45.

[22] Scheffler G, Grunewald J. Material development and optimisation supported by numerical simulation for a capillary-active inside insulation material, in: J. Carmeliet, H. Hens, G. Vermeir (Eds.), Research in Building Physics, A.A. Balkema Publishers, The Netherlands, pp. 77-85; 2003.

[23] Vereecken E, Roels S. A comparison of the hygric performance of interior insulation systems: A hot box-cold box experiment, Energy and Buildings, 2014;80:37-44.

[24] Warren P, Hens H, Hendriks L, Svendson S, Rudbeck C, Stopp H, Makela H, Baker P, Saelens D, Grace M, Inoue T. Integral Building Envelope Performance Assessment, Chapter 5, Technical Synthesis Report, IEA ECBCS Annex 32, ISBN 0-9542670-9-7, FaberMaunsell Ltd, Birmingham; 2003.

[25] Harrestrup M, Svendsen S. Full-scale test of an old heritage multi-storey building undergoing energy retrofitting with focus on internal insulation and moisture, Building and Environment, 2014;85:123133.

[26] Nicolai A, Grunewald J. Delphin 5 Online User Manual, Institute for Building Climatology, University of Technology in Dresden, Dresden; 2005-2006.

[27] Blocken B, Carmeliet J. Spatial and temporal distribution of driving rain on a low-rise building. Wind and Structures 2002, Vol 5, No.5, pp. 441-462.

[28] Kragh MK. Microclimatic conditions at the external surface of building envelopes, Chapter 6. Department of Building and Energy, Technical University of Denmark, Report R-027, ISSN: 13964011, ISBN: 87-7877-028-9; 1998. 
[29] Blocken B, Carmeliet J. The influence of the wind-blocking effect by a building on its wind-driven rain exposure. Journal of Wind Engineering and Industrial Aerodynamics, 2006;94:101-127.

[30] Blocken B, Abuku M, Nore K, Briggen PM, Schellen HL, Thue JV, Roels S, Carmeliet J. Intercomparison of wind-driven rain deposition models based on two case studies with full-scale measurements. Journal of Wind Engineering and Industrial Aerodynamics, 2011;99:448-459.

[31] ISO-standard 15927-3:2009. Hygrothermal performance of buildings - Calculation and presentation of climatic data - Part 3: Calculation of a driving rain index for vertical surfaces from hourly wind and rain data, International Organization for Standardization, ISO Central Secretariat, Geneva; 2009.

[32] Coutu S, Wyrsch V, Rossi L, Emery P, Golay F, Carneiro C. Modelling wind-driven rain on buildings in urbanized area using 3-D GIS and LiDAR datasets. Building and Environment, 2013;59:528-535

[33] Cappelen J, Jørgensen B. Technical report 99-13: Observed Wind Speed and Direction in Denmark with Climatological Standard Normals, 1961-90. Danish Meteorological Institute (DMI), Copenhagen; 1999. http://www.dmi.dk/fileadmin/user_upload/Rapporter/TR/1999/tr99-13.pdf

[34] Hukka A, Viitanen H. A mathematical model of mould growth on wooden material, Wood Science and Technology; 1999;33:475-485.

[35] Vereecken E, Roels S. Review of mould prediction models and their influence on mould risk evaluation, Building and Environment, 2012;51; 296-310

[36] Viitanen H, Ojanen T. Improved Model to Predict Mould Growth in Building Materials, In: Thermal Performance of the Exterior Envelopes of Whole Buildings X - Proceedings CD, 2-7 December, Clearwater Beach, USA, ASHRAE, DOE, ORNL; 2007. 
[37] Ojanen T, Viitanen H, Peuhkuri R, Lähdesmäki K, Vinha J, Salminen K. Mold Growth Modeling of Building Structures Using Sensitivity Classes of Materials. Thermal performance of the exterior envelopes of whole building XI internation conference. Clearwater Beach, Florida pp 1-10; 2010.

[38] Christensen G, Koch AP. Sortsværtning og støvfigurer - heksesod, kuldebroer, statisk elektricitet, ventilation (BYG ERFA erfaringsblad (49) 121229). Ballerup: BYG ERFA (in Danish); 2012. 